\title{
Consumers' Perception towards Private Label and its Implication on Repurchase Intention: A Case of Giant's Customers in Cikarang, Indonesia
}

\author{
Suresh Kumar \\ Business Administration Department \\ President University, Indonesia \\ sureshkumar@president.ac.id
}

\begin{abstract}
Nowadays private label becomes popular in retail industry. For example; Giant provides private label for some of its products like; rice, sugar, cooking oil, and etc. But the question is how the customers perceived it and which variables influence customers' perception in private label. Based on that phenomena this research is aimed to find out the consumers' perceptions towards private label and its implication on repurchase intention. Perceived Price, Perceived Quality, Perceived Risk, and Private Label or Store Label loyalty were chosen for this research for the independent variable, Private label was chosen for its moderating variable and repurchase intention for its dependent variable. A quantitative method was applied with 300 respondents who visited Giant in Cikarang, Indonesia, as the respondents and purposive sampling was used to choose the respondents. Factor analysis was applied to test the construct validity and found the convergence and no discriminant problems were detected. As for the reliability, Cronbach's Alpha was applied and all the variables exceeded 0.6 as the rule of thumb. Perceived price, quality and risk were assessed and found significantly influencing label intention and label intention influences repurchase intention.
\end{abstract}

Keyword: perception, perceived risk, perceived price, perceived quality, repurchase intention

\section{INTRODUCTION}

More and more retail stores are providing products not only coming from the manufacturers but also their own label which is called Private Label. Based on Nielsen Global Private Label Survey 2014, $66 \%$ Indonesians have positive perception regarding private label. With this perception there is a big opportunity for retailers to start providing more and more private label as one of the strategies to win customers.Wu, Yeh, and Hsiao (2011) argue that private label is the way to differentiate from other competitors and build customer loyalty.

From the profit side, it is more profitable to sell private label compare to manufacturers' products as proven by the survey conducted by Food Marketing Institute of US. The survey reveals that retailers earn $35 \%$ gross margin on store branded products compared $25.9 \%$ on comparable nationally advertised brands. Compare to Indonesian market, people's assumption that the national brands have a higher value for money rather than private label brands. This statement is also strengthened by the publication of research conducted by the AC Nielsen Company (2008) which says that more than $40 \%$ of Indonesian consumers believe it is better to buy national brands, despite the fact that more than $50 \%$ of Indonesian consumers have the perception that the quality and packaging of products private label as good as national brands. This perception is arisen because the limited information gathered by consumer about private labels and also advertising about private label is far behind the national's brands. Buying national brand products are somehow prides and trust issues for Indonesians. Some issues like safety, quality, and assumption that private labels are for those who have budget constraint (Seurat Group, 2014).

Research about private label itself is still rare to be found in Indonesia. From portal Portal Garuda, an official government online journal, there were only 30 researches were found about private label of Hypermart, Carrefour and so on which targeting at middle up to high income level people. But none of them were talking about Giant which targeting at middle low income level people. Hence it is crucial to conduct this research to fill up the gap about private label for middle low income people. This research paper will be divided into introduction, literature review, method, findings and discussion and closed with conclusion and recommendation. 


\section{LITERATURE REVIEW}

\subsection{Private Label}

Private label products are products provided by retailers under their name for example Carrefour, Giant, Alphamart, Indomart and many more. They provide private labels mostly for food products like oil, sugar, ketchup and so on, and non-food like tissue, cotton bud and so on. Retailers nowadays provide private labels to attract more and more customers to shop at their retail store and prolong their existence customers to keep on coming to their store ( $\mathrm{Wu}$, Yeh, and Hsiao, 2011). Besides that, private label can also give more profit to retailers because they don't need to pay for the brand anymore hence they can cut the distribution channel. The development of private label is due to customers looking for cheaper price but better quality, thus it makes retailers difficult to gain high profit. Hence, by selling private label cheaper than other brands it will attract more customers and give them higher profit(Wu, Yeh, and Hsiao, 2011). Once the customers experience the private label products, it is hoped that they will do repeat buying or repurchase of the products again in the near future.

\subsection{Customers' Perception}

Perception is the way in which something is regarded, understood, or interpreted (www.oxforddictionaries.com). Customers' perception is a marketing concept that encompasses a customer's impression, awareness and/or consciousness about a company or its offerings through advertising, reviews, public relations, social media, personal experiences and other channels (www.businessdictionary.com).

There are three roles of a customer, namely user, payer and buyer. For the user, the universal value is performance; for the payer, the universal value is price; and for the buyer the universal value is service. Hence, payer will seek for the best price in acquiring the products (Sheth and Mittal, 2004). Based on the research conducted by AC Nielson (2014) towards 30,000 online consumers from 60 countries found that price is important to most consumers and is the primary driver of consumers' purchase intent for private label. In addition to their research, most consumers (67\%) believe private label offers extremely good value for money.

Perceived quality is consumer's opinion of a product's (or a brand's) ability to fulfill his or her expectations based on the firm's (or brand's) current public image, consumer's experience with the firm's other products, and the influence of the opinion leaders, consumer's peer group, and others (www.businessdictionary.com). Perceived quality is the consumer's perception of overall components of product - both tangible and intangible characteristics and may also include performance, features, reliability, conformance, durability, serviceability, and aesthetics etc. (Vantamay, 2007).People tend to avoid product with unrecognized brand, especially when it is cheap, because a good quality product is usually comes with high price (Sudhir, and Talukdar, 2004). That's why private label though it is cheaper than the manufacturer national brand, but it is perceived as a good quality because of the store's name and perceived quality is one of the key factors that influence purchase intention (Kittilertpaisan and Chanchitpreecha, 2013; Vantamay, 2007; Jaafar, Lalp, andNaba, 2013).

Perceived risk is consumer's level of uncertainty regarding the outcome of a purchase decision, especially in case of high priced item such as a car, or a complex item like computer (www.businessdictionary.com). In order to reduce a wrong choice is made, consumers' will collect more extensive information especially for peer group or family members. As for the marketers, to overcome the anxiety of users they give performance warranties, price guarantees. (Seth and Mittal, 2004). They do this because perceived risk influences purchase intention (Jaafar, Lalp and Naba, 2013; Kristof De Wulf, Gaby Odekerken-Schröder, Frank Goedertier, Gino Van Ossel, 2005).

Brand loyalty is defined as the attachment that a customer has to a brand. It reflects how likely a customer will be to switch to another brand, especially when that brand makes a change, either in price or in product features (Aaker, 1991). On the other hand, Oliver (1997) defined brand loyalty as a deeply held commitment to rebuy or re-patronize a preferred brand consistently in the future, despite situational influences. Poral and Lang (2014) found that brand loyalty or in retail case, store loyalty or private loyalty, strongly influences purchase intention. Previously Poral and Boga (2013) has also found similar results. 


\subsection{Repurchase Intention}

Repurchase intention has been a subject for many researches since repurchase intention is one of the drivers for loyal customers. Without loyal customers, it can be said that the retailers are waiting for their doom's day. Many ways have been done by retailers to have the customers return and repurchase at their store like price discount, promotion until providing private label with cheaper price but not less quality (Levy, Weitz and Grewal,2016). Repurchase intention is the desire of customers to shop again at the retail store or shop the goods for the second time or more.

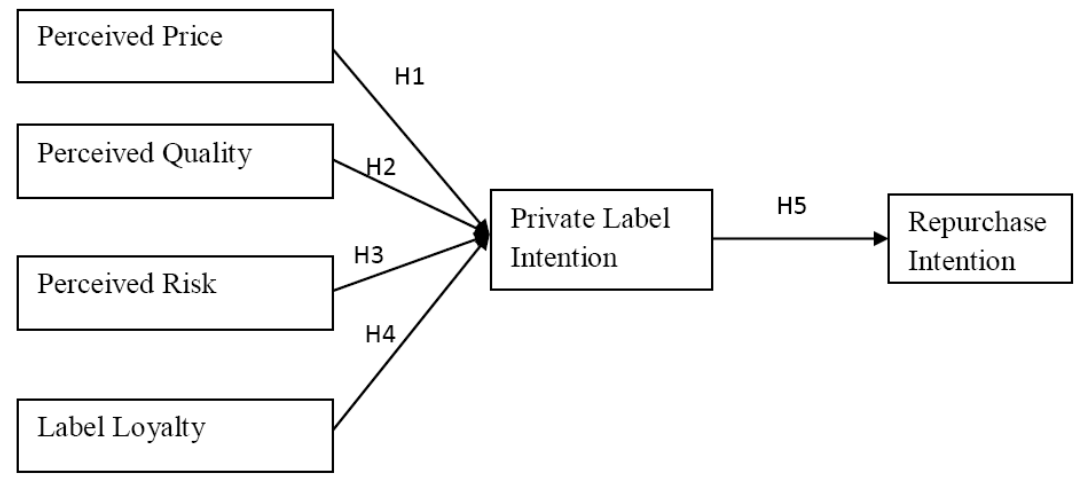

Figure1. Theoretical Framework and Hypotheses

\section{Hypotheses}

H1: Perceived Priceinfluences Private label intention

H2: Perceived QualityinfluencesPrivate label intention

H3: Perceived RiskinfluencesPrivate label intention

H4: Label loyaltyinfluencesPrivate label intention

H5: Private label intentioninfluencesRepurchase intention

\section{3. МЕTHOD}

The population of this research was any individuals who shopped at Giant - Cikarang, located in West Java Province in Indonesia, whether they were males or females.Sample size gathered was 375 respondents distributed to 230 females $(61 \%)$ and 145 males (39\%), thus it has satisfied to be further process using factor analysis and structural equation model (Hair, 2010). Due to researcher limitation, hence the convenience sampling method was applied from non-probability sampling. The researchers distributed the survey instrument, questionnaire, directly to the customers' of Giant in the parking lot and food court. The duration of data gathering was from the first week of April until the first week of May 2016.Most of the respondents were coming from the age of 18-25 years old (81\%), followed by $36-45$ years old (12\%), 45 years old (6\%), and 26-35 years old (1\%). Regarding the marital status, most respondents were bachelor $(80 \%)$ and married $(20 \%)$. As for income level, most respondents earned less than IDR 5,000,000 (89\%), between IDR 5,000,001 and 9,000,000 there were 7\% and the rest earned between IDR 9,000,001 and 12,000,000 (4\%). Respondents' monthly expenses were also inquired with the result, majority of them spent less than IDR 2,000,000 (85\%), between IDR $2,000,001$ and 3,000,000, there were $8 \%$ and the rest spent more than IDR 3,000,000 (7\%). Other criterion set was that all respondents had at least once bought Giant Private Label.

The validity and reliability of data were checked before further processing. Factor analysis was applied for construct validity and for the rule of thumb KMO and Bartlett' and Cronbach's Alpha was applied for reliability test for each of the factor.

From Table 1, for Consumer Perception (Price, Quality, Risk and Label Loyalty) factor, KMO and Bartlett's test was conducted and found out that it was greater than $0.5(0.897)$ and significant test was below 0.05 (0.0001); communalities were above 0.5 (ranging from 0.736 till .870 ) and total variance explained was at least $60 \%(81.046 \%)$. As factor loading it exceeded 0.3 (ranging from 0.735 till 0.826). From Rotated Component Matrix, it shows that item question Price1, Price2, and Price3 converged only on Price Factor (convergent validity) and has low correlation (below 0.44) among other item questions (discriminant validity). Since Private Label Intention and Repurchase Intention have only one factor each hence there is no Rotated Component Matrix built. It also shows Cronbach's Alpha above 0.6 (ranging from 0.788 till 0.871). 


\section{Suresh Kumar}

From Table 1, for Private Label Intention factor, KMO and Bartlett's test was conducted and found out that it was greater than $0.5(0.719)$ and significant test was below $0.05(0.0001)$; communalities were above 0.5 (ranging from 0.521 till .728) and total variance explained was at least $60 \%$ (63.688\%). For reliability test, Cronbach's Alpha shows above $0.6(0.807)$.

From Table 1, for Repurchase Intention factor, KMO and Bartlett's test was conducted and found out that it was greater than $0.5(0.683)$ and significant test was below $0.05(0.0001)$; communalities were above 0.5 (ranging from 0.657 till .794) and total variance explained was at least $60 \%(71.926 \%)$. For reliability test, Cronbach's Alpha shows above 0.6 (0.803).

Since the Consumer Perception (Price, Quality, Risk and Label loyalty) factor, Private Label Intention and Repurchase Intention have valid and reliable data, therefore the data are ready for further analysis using Structural Equation Modelling (SEM).

Table1. Validity and Reliability Test

\begin{tabular}{|c|c|c|c|c|c|}
\hline Factor & $\begin{array}{l}\text { Factor } \\
\text { Loading }\end{array}$ & $\begin{array}{l}\text { KMO and } \\
\text { Bartlett's Test }\end{array}$ & Communalities & $\begin{array}{l}\text { Total Varianced } \\
\text { Explained }\end{array}$ & Reliability \\
\hline Price 1 & .826 & \multirow{10}{*}{$.897 ; .0001$} & .842 & \multirow{10}{*}{$81.046 \%$} & \multirow{3}{*}{.840} \\
\hline Price 2 & .754 & & .736 & & \\
\hline Price 3 & .735 & & .741 & & \\
\hline Quality 1 & .808 & & .789 & & \multirow{3}{*}{.871} \\
\hline Quality 2 & .808 & & .824 & & \\
\hline Quality 3 & .789 & & .790 & & \\
\hline Risk 1 & .819 & & .870 & & \multirow{2}{*}{.800} \\
\hline Risk 2 & .748 & & .838 & & \\
\hline Label 1 & .821 & & .839 & & \multirow{2}{*}{.788} \\
\hline Label 2 & .778 & & .836 & & \\
\hline Intention 1 & & \multirow{4}{*}{$.719 ; .0001$} & .632 & \multirow{4}{*}{$63.688 \%$} & \multirow{4}{*}{.807} \\
\hline Intention 2 & & & .666 & & \\
\hline Intention 3 & & & .521 & & \\
\hline Intention 4 & & & .728 & & \\
\hline Repurchase1 & & \multirow{3}{*}{$.683 ; .0001$} & .657 & \multirow{3}{*}{$71.926 \%$} & \multirow{3}{*}{.803} \\
\hline Repurchase2 & & & .707 & & \\
\hline Repurchase3 & & & .794 & & \\
\hline
\end{tabular}

\section{FINDINGS AND DISCUSSIONS}

Through structural equation modelling (Figure 1), it shows that relationship among the exogenous and endogenous. Later, it is extracted to find out the good fit from several measurements, like Chi Square, CMIN/DF, NFI, IFI, RMSEA, CFI and TLI. From Table 2, it shows that all the measurements are in good fit; hence the data are eligible to be interpreted.

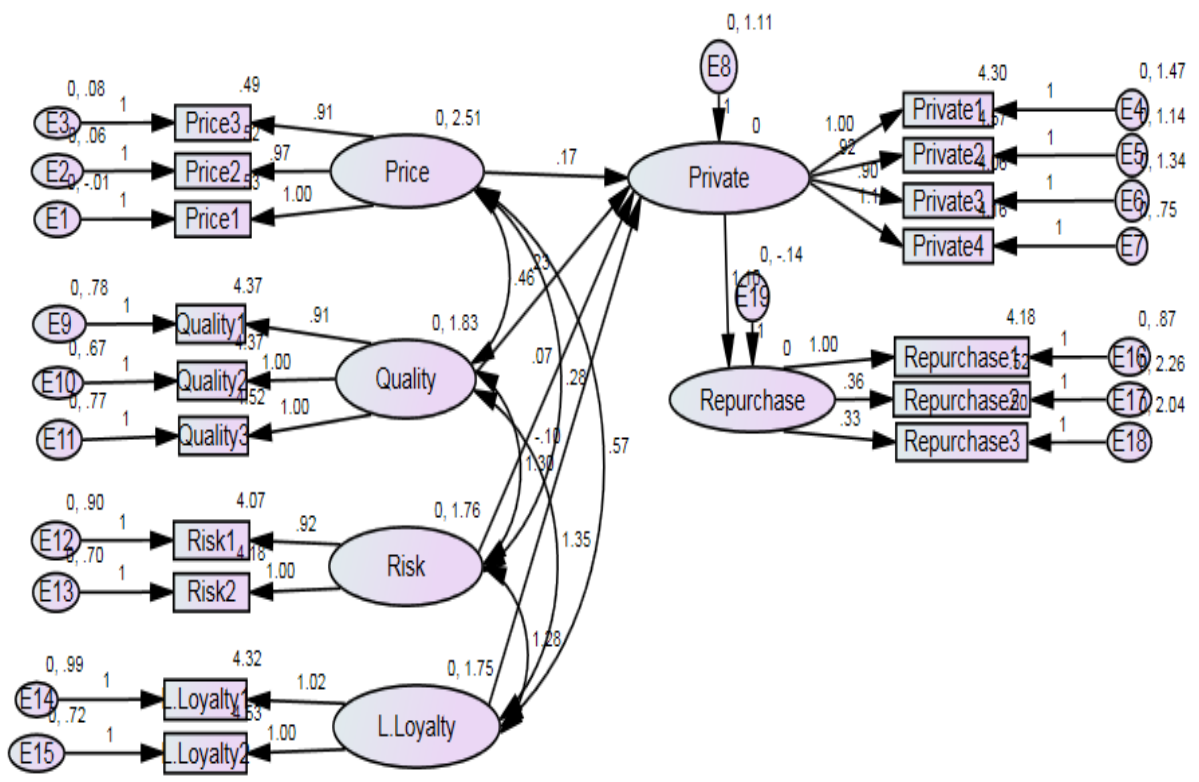

Figure2. Structural Equation Modelling 
Consumers' Perception towards Private Label and its Implication on Repurchase Intention: A Case of Giant's Customers in Cikarang, Indonesia

Table2. Goodness of Fit

\begin{tabular}{|l|l|l|l|}
\hline Criteria & Good Fit Value & Result & Interpretation \\
\hline Chi Square & $\mathrm{P}<0.05$ & .000 & Good fit \\
\hline CMIN/DF & $2.00 \leq \mathrm{x} \leq 5.00$ & 3.445 & Good fit \\
\hline NFI & $\geq 0.80$ & 0.945 & Good fit \\
\hline IFI & $\geq 0.80$ & 0.960 & Good fit \\
\hline RMSEA & $\leq 0.08$ & 0.07 & Good fit \\
\hline CFI & $\geq 0.95$ & 0.960 & Good fit \\
\hline TLI & $\geq 0.90$ & 0.943 & Good fit \\
\hline
\end{tabular}

Table3. Regression Weights

\begin{tabular}{|l|l|l|l|l|l|l|l|}
\hline & & & Estimate & S.E. & C.R. & P & Label \\
\hline Private & $<---$ & Price & .089 & .031 & 2.821 & .005 & par_6 \\
\hline Private & $<---$ & Quality & .185 & .087 & 2.137 & .003 & par_10 \\
\hline Private & $<---$ & Risk & .090 & .081 & 2.109 & .002 & par_13 \\
\hline Private & $<---$ & Label & -.089 & .048 & -1.867 & .062 & par_22 \\
\hline Repurchase & $<---$ & Private & 1.090 & .085 & 12.780 & $* * *$ & par_17 \\
\hline
\end{tabular}

H1: Price Perceptionhas impact on Private label intention

The C.R value of price perception to Private label intention is 2.821 which is greater than 1.96 and $p$ value is 0.005 which is less than 0.05 . The estimation value is .089 and it shows positive sign. It indicates price perception has positive impact on private label intention significantly ( $\mathrm{H} 1$ is accepted).

H2: Quality perception will have a positive impact on Private label intention

The C.R value of quality perception to Private label intention is 2.137 which is greater than 1.96 and $p$ value is 0.033 which is greater than 0.05 . The estimation value is .185 and it shows positive sign. It indicates quality perception positively influence the private label intention significantly $(\mathrm{H} 2$ is accepted).

H3: Risk perception will have a positive impact on Private label intention

The C.R value of risk perception to Private label intention is 1.109 which is greater than 1.96 and $p$ value is 0.002 which is less than 0.05 . The estimation value is .09 and it shows positive sign. It indicates risk perception positively influence the private label intention significantly. (H3 is accepted).

H4: Label loyalty will have a positive impact on Private label intention

The C.R value of label loyalty to Private label intention is -1.867 which is smaller than 1.96 and $p$ value is .062 which is greater than 0.05 . It indicates label loyalty is not influencing the private label intention significantly ( $\mathrm{H} 4$ is rejected).

H5: Private label intention will have a positive impact on Repurchase intention

The C.R value of private label intention to Private label intention is 12.780 which is greater than 1.96 and $p$ value is .0001 which is less than 0.05 . The estimation value is 1.090 and it shows positive sign.It indicates private label intention positively influence the repurchase intention significantly (H5 is accepted).

\section{CONCLUSION AND RECOMMENDATION}

Price, Quality, and Risk perception have strong positive influence on Private LabelIntention, whereas Label Loyalty has no influence on Private Label Intention. As for Repurchase Intention, it is strongly influenced by Private Label Intention.

In retail industry now on, we can find many kinds of product varieties and assortments. Also the competition among retailers are increasing looking at the numbers of retailers are increasing year by year in Indonesia,hence the way to survive from that competition is to give customers with a new experience, new innovation, and make the store always on top of mind. Private label is one of the examplesof solution. Not only it benefits the retailers by making more profit but also it helps customers by having cheaper price but not less quality. This is the risk that customers are willing to take which is shown in this research. But managers can't count on the label loyalty too much since it was rejected in this research. Repurchase intention can also be triggered by having a good quality of 
Private Label. The key to success of any retailers if they can have many loyal customers and one of the key drivers is by having repurchase intention of their customers

This research is expected to be extended to other cities, provinces or even national wide to have a better generalization results. Having a more homogenous respondent per say, the same level of income, it will give a better result to which target the Private Label should be aimed.

\section{REFERENCES}

[1] AC Nielsen. (2014). The State of Private Label around the World. Retrieved from http://www.nielsen.com/content/dam/nielsenglobal/kr/docs/global-report $/ 2014 /$ Nielsen $\% 20$ Global\%20Private\%20Label\%20Report\%20November\%202014.pdf.

[2] Wu, P.C.S., Yeh, G. Y. and Hsiao, C.R. (2011). The Effect of Store Image and Service Quality on Brand Image and Purchase Intention for private label brands.Australasian Marketing Journal.Vol 19.No. 4. Pp. 30-39

[3] Seurat Group. (2014). Retail Today: Creating Leverage in a no Growth Industry. Retrieved from http://www.seuratgroup.com/uploads/files/retail-today-creating-leverage-in-a-no-growthindustry-10.pdf

[4] Sheth, J.N., Mittal, B. Customer Behavior: A Managerial Perspective. Ohio: Thompson SouthWestern.

[5] Vantamay, S. (2007). Understanding of Perceived Product Quality: Reviews and Recommendations. Retrieved from www.bu.ac.th/knowledgecenter/epaper/jan_june2007/ Somphol.pdf

[6] Sudhir, K and Talukdar, D. (2004). Does store brand patronage improve store patronage? Review of Industry Organization.Vol. 24(2). pp. 143-160.

[7] Kittilertpaisan, J., Chanchitpreecha, C. (2013). Consumer Perception on Purchase Intention towards Koa Hang: An Exploratory Survey in Sakon Nakhon Province. International Conference on Entrepreneurship and Business Management. Sanur - Bali

[8] Jaafar, S.N., Lalp, P.E., Naba, M.M., (2013). Consumers' Perceptions, Attitudes and Purchase Intention towards Private Label Food Products in Malaysia.Asian Journal of Business and Management Sciences. Vol 2. No. 8 [73-90].

[9] Kristof De Wulf, Gaby Odekerken-Schröder, Frank Goedertier, Gino Van Ossel, (2005) "Consumer perceptions of store brands versus national brands", Journal of Consumer Marketing, Vol. 22 Iss: 4, pp.223 - 232

[10] Aaker, D.A. (1991). Managing brand equity, capitalizing on the value of a brand name.The Free Press, New-York, N.Y.

[11] Oliver, R.L. (1997). Satisfaction: A Behavioral Perspective on the Consumer. New York: McGrawHill

[12] Porral, C.C., Lang, M.F., (2015),"Private labels", British Food Journal, Vol. 117 Iss 2 pp.506 522

[13] Porral, C.C., Boga, O.J. (2013). Measuring the influence of customer-based store brand equity in the purchase decision. Cuadernos de Gestion. Vol. 15.No.1. pp. 93-118.

[14] Levy, M., Weitz, B., Grewal, D. (2016). Retailing Management. ${ }^{\text {th }}$ Ed. New York: McGrawHill/Irwin.

[15] Hair, J.F., et al. (2010). Multivariate data analysis.(7th edition). New Jersey : Pearson Education Inc. 